\title{
The Effect of Trichoderma Seed Priming to Drought Resistance in Tomato (Solanum lycopersicum L.) Plants
}

\author{
Domates Bitkisinde (Solanum Iycopersicum L.) Tohumların \\ Trichoderma ile Ön Muamelesinin Kuraklık Direncine Etkisi \\ Research Article \\ Necla Pehlivan ${ }^{*}$, Neslihan Saruhan Güler ${ }^{2}$, Şengül Alpay Karaoğlu' ${ }^{1}$ \\ 'Department of Biology, Faculty of Arts and Sciences, Recep Tayyip Erdogan University, Rize, Turkey. \\ ${ }^{2}$ Department of Nutrition and Dietetics, Faculty of Health Sciences, Karadeniz Technical University, Trabzon, Turkey.
}

\section{A B S TR AC T}

\begin{abstract}
Tomato is one of the most important food crops immensely affected by water scarcity. Therefore, it is vital to find biocontrol agents for improving the yield of tomato crop in arid areas. The fungal genus, Trichoderma is widely used as an eco-friendly, biocontrol agent in commercial formulas because of the various beneficial effects it has on plants including the resistance to biotic and abiotic stresses. In the present study, the effects of an isolate of Trichoderma atroviride ID20G (Ta) on tomato (Solanum lycopersicum L.) seedlings were investigated under drought stress. The isolated fungus was identified using ITS (internal transcribed spacer) sequences. Root colonization by Ta induced changes in growth performance indexes such as root growth, root branching, and leaf number as compared to the untreated seedlings. Chlorophyll and carotenoid contents of the untreated tomato seedlings decreased after drought stress along with extensive membrane deterioration, whereas seed colonization by Ta prevented lipid oxidation and ameliorated the harmful effects of drought on pigment contents. Antioxidant enzyme activity was elevated and hydrogen peroxide $\left(\mathrm{H}_{2} \mathrm{O}_{2}\right)$ concentration was found to decrease under drought stress in the Ta treated seedlings. These observations suggest that colonization of tomato seedlings by Ta is effective in counteracting the injurious effects of drought, and therefore, may have a prominent role in increasing the drought tolerance of tomato plant by decreasing $\mathrm{H}_{2} \mathrm{O}_{2}$ concentration and activating the antioxidant enzymes. Furthermore, fungus-based biocontrol agent formulation of Ta might serve as a potential tool in tomato agriculture owing to its low cost, effectiveness, and characteristics required for balancing the natural ecology.
\end{abstract}

\section{Key Words}

Seed priming, drought, tomato, Trichoderma atroviride ID20G.

\section{öz}

\begin{abstract}
D omates, su kıtlığından etkilenen en önemli besin ürünlerinden biridir. Bu nedenle kurak bölgelerde yetişen domates verimini arttırmak için biyokontrol ajanları bulmak hayati önem taşır. Trichoderma mantar cinsi, biyotik ve abiyotik streslere direnç de dahil olmak üzere bitkiler üzerinde sahip olduğu çeşitli yararlı etkiler sayesinde ticari formüllerde çevre dostu bir biyolojik kontrol ajanı olarak yaygın şekilde kullanılmaktadır. Bu çalışmada, Trichoderma atroviride ID20G (Ta) izolatının kuraklık stresi altında domates bitkilerindeki (Solanum Iycopersicum L.) etkileri araştırılmıştır. İzole edilen mantar, ITS (internal transcribed spacer) dizileri kullanılarak tanımlanmıştır.Ta kök kolonizasyonu, uygulama yapılmamış bitkilere nazaran kök büyümesi, kök dallanması ve yaprak sayısı gibi büyüme performansı endekslerinde değişiklikler meydana gelmesini sağlamıştır. Mantar ile muamele edilmemiş domates bitkilerinin klorofil ve karotenoid içerikleri ağır membran hasarı ile birlikte kuraklık stresi sonrasında azalırken, tohumların Ta ile muamele edilmesi lipit oksidasyonunu önlemiş ve kurakı̆ğın pigment içeriğindeki zararlı etkilerini azaltmıştır. Antioksidan enzim aktivitesi yükselmiş ve Ta ile muamele edilen kuraklık stresi altındaki bitkilerde hidrojen peroksit $\left(\mathrm{H}_{2} \mathrm{O}_{2}\right)$ konsantrasyonunun azaldığı görülmüştür. Bu gözlemler, domates tohumlarının Ta ile muamelesinin, kuraklığın zararlı etkilerine karşı etkili olduğunu ve antioksidan enzimleri aktive ederek $v \mathrm{H}_{2} \mathrm{O}_{2}$ konsantrasyonunu azaltarak domates bitkisinin kuraklık toleransını arttırmada önemli bir role sahip olabileceğini önermektedir. Dahası, Ta mantarı tabanlı bir biyo-kontrol ajan formülasyonu, düşük maliyetli olması, etkinliği ve ekolojiyi dengeleyebilecek özelliklerden dolayı domates tarımı için potansiyel bir araç görevi görebilir.
\end{abstract}

\section{Anahtar Kelimeler}

Tohuma ön muamele, kuraklık, domates, Trichoderma atroviride ID20G.

Article History: Received: Jan 31, 2018; Revised: Feb 19, 2018; Accepted: Mar 2, 2018; Available Online: Mar 26, 2018.

DOI: 10.15671/HJBC.2018.234

Correspondence to: N. Pehlivan, Dept of Biology, Faculty of Arts and Sci., Recep Tayyip Erdogan Uni., Rize, Turkey. 


\section{INTRODUCTION}

D rought is the main cause of loss of crop biomass and yield across the world. Based on the statistics, the drought-affected land has more than doubled in the recent years [1]. It is visualized as one of the most important threats to agriculture in the near future. Basic agricultural practices are remarkably affected by drought stress due to the fluctuations in global climate, reduction in rainfall, and a decrease in soil fertility. This decrease may be attributed to the use of chemical and/or synthetic fertilizers across the globe [1]. To avoid the catastrophic effects of drought stress, it is fundamental to look for alternative ways to obtain better soil fertility and stimulate the growth of plants. Thus, mankind is in need of some nature-friendly biocontrol agents that might help to overcome injurious effects of drought. One of the best ecofriendly biocontrol agents for plants is the genus, Trichoderma. Trichoderma is a cosmopolitan fungus belonging to the family, Hypocreaceae, and is commonly found in the rhizosphere as well as in agricultural areas, forests, or in different zones and ecosystems. They may also be present as parasites together with other fungi. Trichoderma spp. is broadly utilized as biofertilizers and/or biopesticides in commercial formulas because of their multiple beneficial effects on plant growth [2]. Furthermore, Trichoderma genus releases some metabolites analogous to phytohormones, which in turn induce growth under stress.

Plant cells can generate reactive oxygen species (ROS) even under normal conditions; however, these get eliminated by defense mechanisms of the cell. Under stressful conditions, such as drought, oxidative stress is induced by the generation of ROS [3]. Nevertheless, plants have defense mechanisms, both enzymatic and non-enzymatic (antioxidants) against ROS. The enzymatic components include superoxide dismutase (SOD), ascorbate peroxidase (APX), catalase (CAT), and glutathione reductase (GR), whereas the non-enzymatic ones are ascorbic acid (ASA) and glutathione (GSH). Mitigation of ROS employed by Trichoderma genus has been demonstrated as one of the important mechanisms in plants under drought stress. In recent years, several studies have suggested that colonization of plants with Trichoderma enhances the water-stress tolerance of plants through the regulation of expression of genes coding for antioxidant enzymes or transcription factors [4]. In a previous work of our lab, the presented data proved that Trichoderma atroviride ID20Ginoculated seedlings demonstrated increased antioxidant activity than the uninoculated ones under drought stress conditions [5]. In addition, several studies have shown that root colonization by Trichoderma result in increased levels of plant enzymes consisting of different peroxidase types, chitinases, glucanases, lipoxygenases, and phytoalexins-like compounds that provide reliable protection against oxidative stress $[6,7]$.

Tomato (Solanum lycopersicum L.) is one of the most consumed crops worldwide. According to a 2015 report by Food and Agriculture Organization (FAO) [8], fresh fruit production of tomato increased to 160 million tons in 2013. Because of its excellent nutritional value, the tomato is either consumed as a fresh or processed fruit. Additionally, it is a great source of vitamins, folate, and some phytochemicals [9]. Tomato plants need a well-irrigated system, and unfortunately, most of the cultivars are drought sensitive at all steps of plant development. However, seed germination and early seedling growth are the most sensitive stages. Since tomato growth and yield are severely threatened by various abiotic factors, the use of nature-friendly Trichoderma strains may be a suitable strategy for improving the yield of tomatoes in arid areas.

Although many studies report different scenarios to mitigate drought stress-mediated damage with the help of Trichoderma genus, no direct evidence is present as to whether this newly identified T. atroviride ID20G (our local fungal strain) induces stress tolerance in tomato plants. At the same time, it may be important to examine the locally and newly defined biocontrol agents under drought conditions, since new isolates might have different protection mechanisms due to their ecotypic variations and genetic backgrounds. Therefore, the objective of the present investigation was to evaluate whether Ta can serve as a candidate strain for controlling abiotic stress in tomato, thereby increasing the 
drought tolerance of the plant, and to explain the underlying fundamental physiological and biochemical changes associated with its practice as a seed inoculant before germination stage.

\section{MATERIAL and METHODS Isolation and Identification of Ta}

The various strains of Trichoderma were formerly isolated with the method demonstrated by [10] from a tea cultivation area of Rize province of Turkey. Molecular identification was performed as described by [5]. The target strain of Trichoderma named as ID20G was used as a seed biopriming agent for the present study.

\section{Plant Material and Preparation of Ta Formulation}

Hyphae and spores of Ta were produced as described by [5] from 14-day-old strains. Measurements of the fungal inoculation ( $\mathrm{Ta}, 1$ $410^{7}$ conidia $/ \mathrm{mL}$ ) and the conidial densities in the suspension were determined based on the methods mentioned by [5]. Seed inoculation was conducted on the tomato seeds (Solanum lycopersicum L.) in the adjusted amount of microbial suspension. Seeds were sterilized using $1 \%$ bleach. After $20 \mathrm{~min}$, seeds were washed in sterile distilled water several times and submerged in $50 \mathrm{~mL}$ of a spore suspension ( $\mathrm{Ta}, 1+$ $10^{7}$ conidia/mL) and incubated for $1 \mathrm{~h}$. The control group of seeds was placed in the same volume of distilled water for $1 \mathrm{~h}$.

\section{Pot Experiment}

Plant soil was autoclaved twice for $1 \mathrm{~h}$ before its transfer to polyethylene bags. Six seeds were placed in each pot and put into a growth chamber with $16 \mathrm{~h}$ of light/ $8 \mathrm{~h}$ of dark period at $25^{\circ} \mathrm{C}$. The effects of Ta on the growth of tomato seedlings were assayed after four weeks of daily watering. Drought stress was mimicked by withholding water after four weeks of germination for 12 days. Control plants were irrigated with tap water as the same stress period of drought plants. Afterward, the seedlings were arranged as listed: treated with plain water (untreated control, C), pre-treated with Ta and not drought stressed ( $\mathrm{Ta}$ ), drought-stressed only (DS), and pre-treated with Ta and drought-stressed (Ta + DS).

\section{Macroscopic Phenotyping Analysis of the Target Fungus}

At the end of experimental period, the roots were separated from the soil under sterile conditions and washed directly with sterile water. They were then examined directly on a stereo microscope (Leica S6 D Product; Leica Microsystems, Wetzlar, Germany) to check if the Ta was actually present in the environment and absent from the control group. Cotton blue staining was performed to distinguish the fungus hyphae from the plant roots, and the samples were inspected under the microscope. Thin long filamentous hyphal structure with septum was accepted as Ta. After the roots were separated from the soil, they were washed with ethanol (70\%) and small pieces (three pieces for each group) were cut for further use by scalpel and placed onto the dichloran rose-bengal chloramphenicol (DRBC) agar under sterile conditions. Pictures were taken before and after four days of incubation at $28^{\circ} \mathrm{C}$.

\section{Analyses of Chemical Compounds}

The second fully developed apical leaves were used to measure photosynthetic pigment contents, namely total chlorophyll (chl) and total carotenoid (car) by acetone (80\%) extraction method. Absorbance measurements were obtained at 663 , 645 , and $450 \mathrm{~nm}$ by an ultraviolet-visible (UVVIS) absorption spectrophotometer (Biochrom Libra S70, UK) [11,12].

The rate of oxidation of lipids (fatty acids) was measured via the concentration of malondialdehyde (MDA, e $=155 \mathrm{mM}^{-1} \mathrm{~cm}^{-1}$ ) with the help of the basic method of Heath and Packer [13].

The accumulation of endogenous hydrogen peroxide $\left(\mathrm{H}_{2} \mathrm{O}_{2}\right)$ was assayed with the help of the method described by Velikova et al. [14].

\section{Antioxidant Enzyme Assays}

Extractions for the activity assays were performed in $50 \mathrm{mM}$ of potassium phosphate $\left(\mathrm{K}_{2} \mathrm{HPO}_{4}\right)$ buffer $(\mathrm{pH} 7.0)$ set up with $1 \%$ polyvinylpolypyrrolidone and $1 \mathrm{mM}$ EDTA mix. Bovine serum albumin as a standard was used for soluble protein content calculations [15]. 
Superoxide dismutase (SOD; EC, 1.15.1.1) activity was detected based on the method of Beauchamp et al. [16]. The activity of guaiacol peroxidase (GPX; EC, 1.11.1.7) was detected as the increase in $470 \mathrm{~nm}$ absorbance $\left(25^{\circ} \mathrm{C}, \mathrm{e}=26.6\right.$ $\mathrm{mM}^{-1} \mathrm{~cm}^{-1}$ ) [17]. Catalase (CAT; EC, 1.11.1.6) activity was assayed by an $\mathrm{H} 2 \mathrm{O} 2$ decrease $\left(25^{\circ} \mathrm{C}\right.$, e $=39.4$ $\mathrm{mM}^{-1} \mathrm{~cm}^{-1}$ ) at $240 \mathrm{~nm}$ [18]. Ascorbate peroxidase (APX; EC, 1.11.1.11) activity was measured via oxidation of the ascorbate at $290 \mathrm{~nm}\left(25^{\circ} \mathrm{C}\right.$, e = $2.8 \mathrm{mM}^{-1} \mathrm{~cm}^{-1}$ ) [19].

\section{Statistical Analysis}

Data were evaluated by SPSS Version 15.0 (SPSS Inc., USA). Duncan's multiple range test was applied for the analysis of mean values. The statistical significance of differences was set to a level of $5 \%(p<0.05)$.

\section{RESULTS}

\section{Macroscopic Phenotyping Analysis of the Target Fungus}

We initially checked if Ta was actually present in the environment and absent in the control group. We tested this notion in the roots and did not find any other fungus phenotype (Figure 1). The data demonstrated that Ta treatment has an important effect on tomato growth. We found that it particularly improved the root development even under normal conditions without drought (Figure 2). The number of roots and leaves for Ta-treated
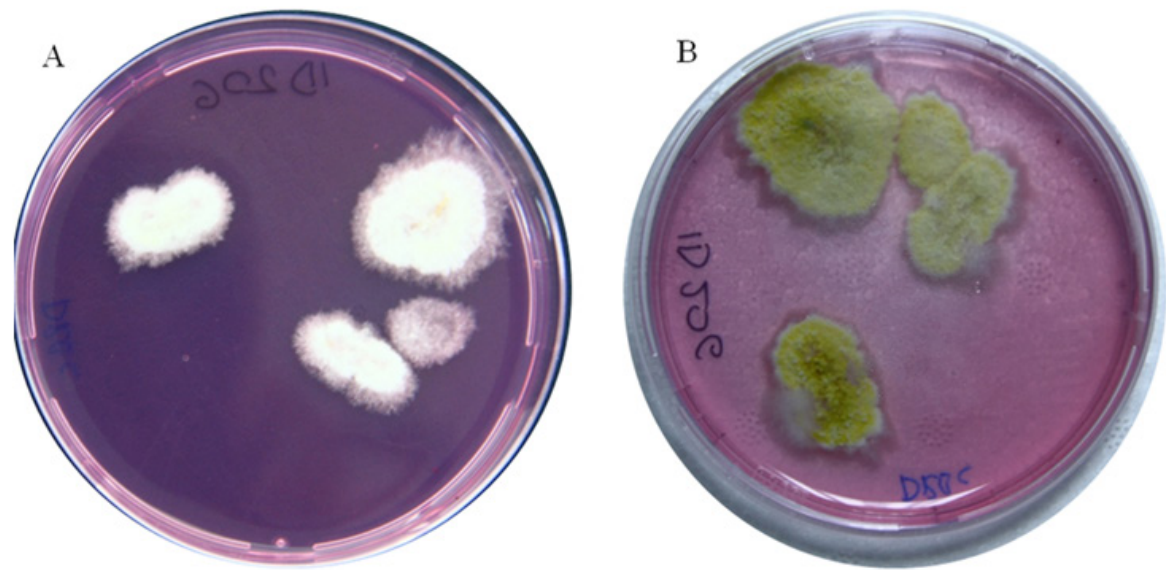

Figure 1. Contamination test of tomato root samples on DRBC agar (Dichloran Rose Bengal Chloramphenicol Agar) before $(A)$ and after $(B)$ the sporulation phase.
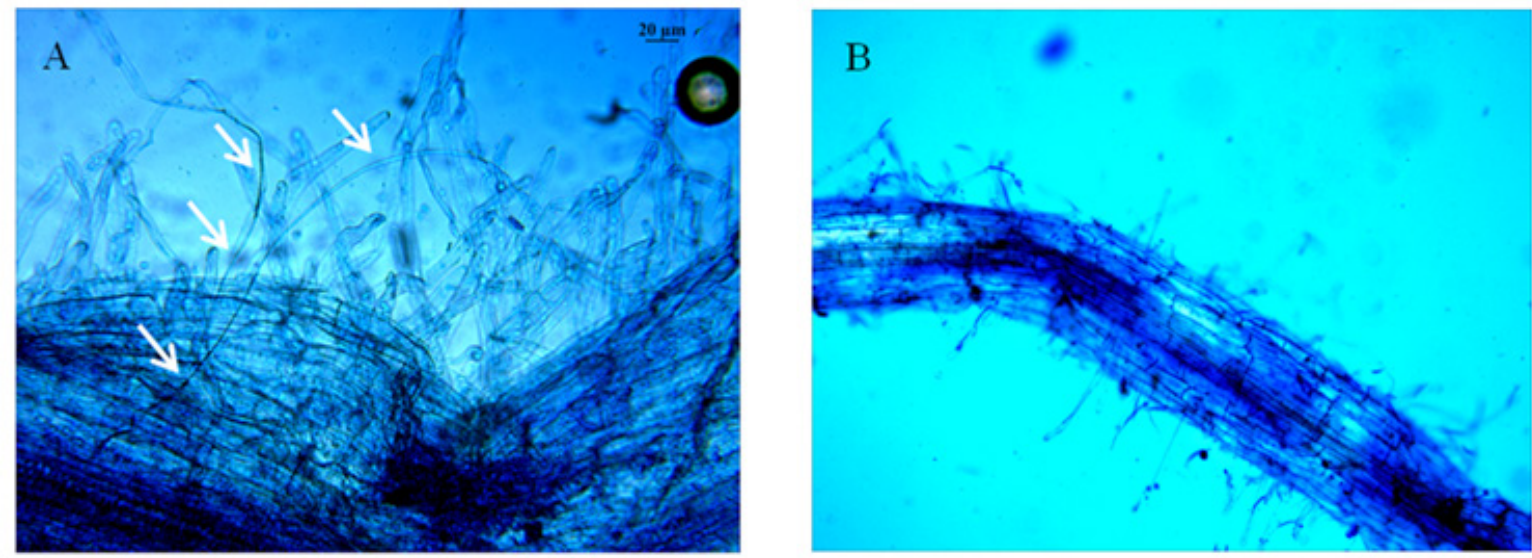

Figure 2. Root staining analysis with (A) or without (B) ID20G inoculation. The presence of ID20G hyphae was detected by staining the tomato roots with cotton blue (chitin staining dye). White arrows indicate ID20G hyphae. 


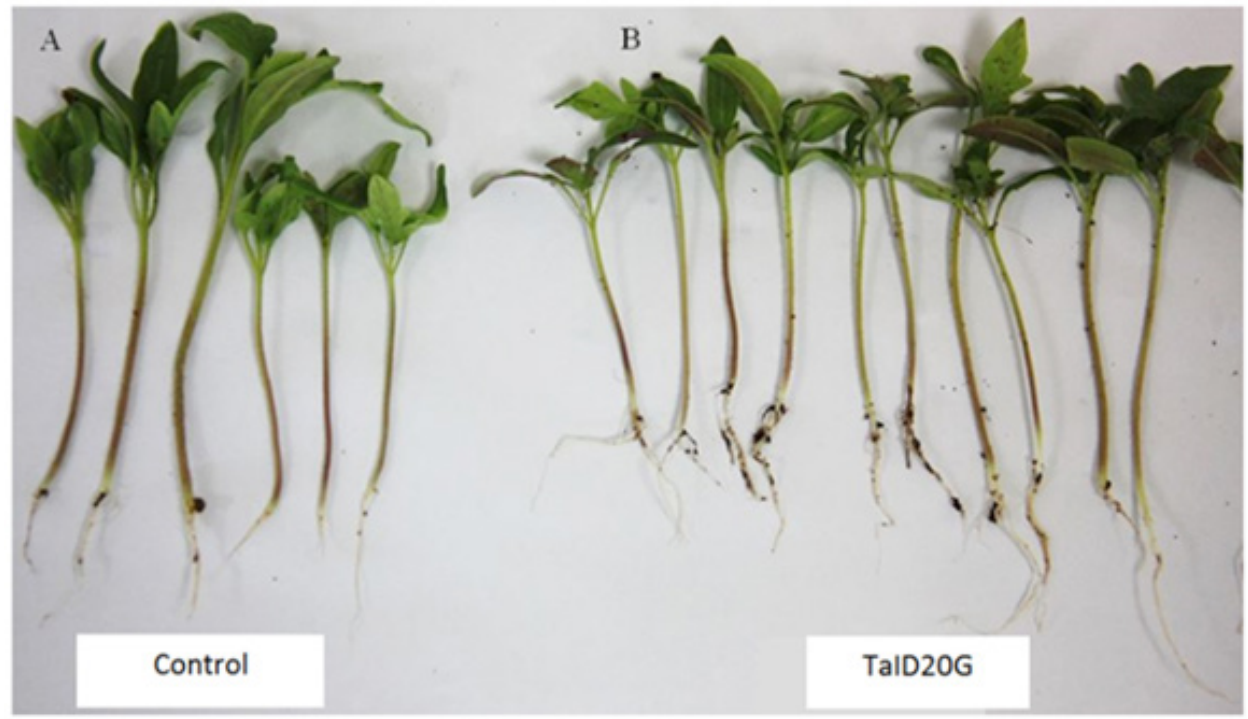

Figure 3. Stimulation of tomato root growth by Trichoderma strain ID20G under normal (no drought) Control (A) and ID20G inoculated (B) conditions.
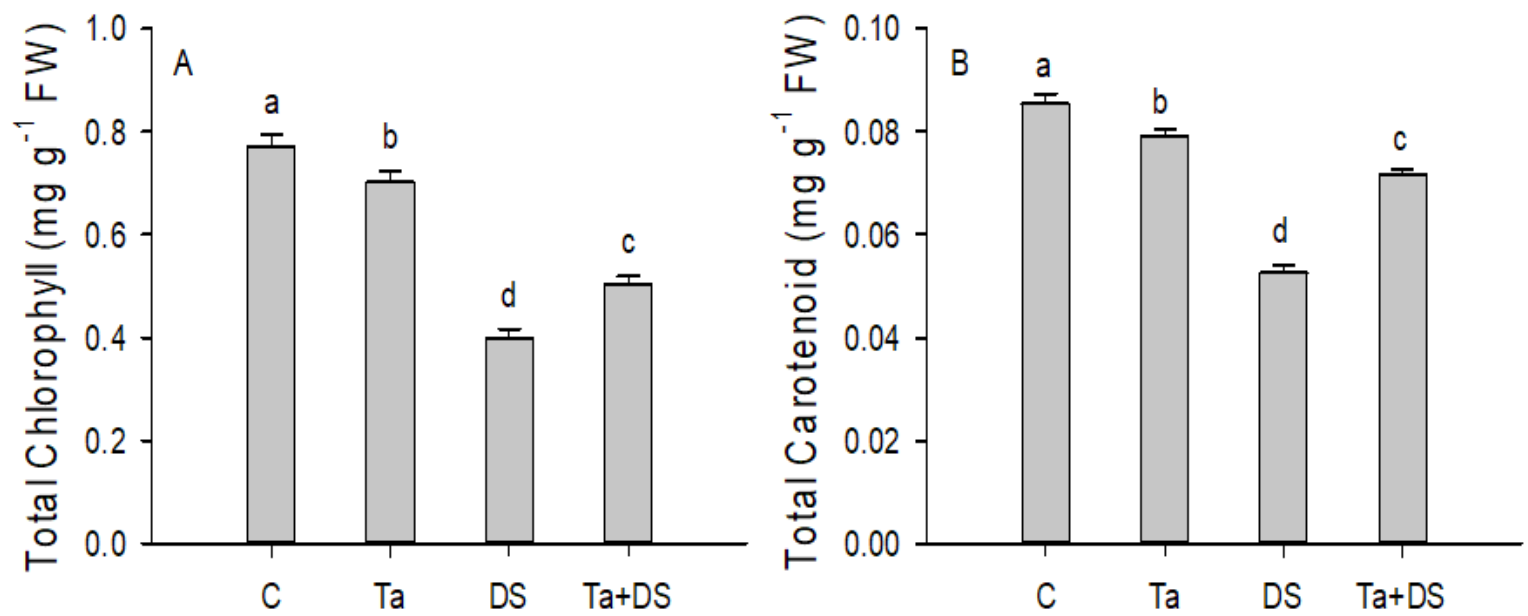

Figure 4. The potency of seed biopriming of T. atroviride strain ID20G on total chlorophyll (A) and total carotenoid (B) contents of tomato plants under drought stress. The plants were subjected to four treatments: with distilled water (untreated control, C), with T. atroviride strain ID20G and not drought stressed (Ta), drought-stressed only (DS), and pretreated with $T$. atroviride strain ID20G and drought stressed (Ta+DS). FW: Fresh weight. Vertical bars indicate standard deviation and different letters indicate significant difference $(P<0.05)$ among the treatments.

tomato seedlings was significantly higher than the untreated ones (Figure 3).

\section{Ta Inoculation Under Drought Improves \\ Photosynthetic Pigments}

Drought stress significantly increased the percent reduction of pigment contents in tomato seedlings. The percent decrease rate was calculated to be $48.5 \%$ and $38.4 \%$ in total chlorophyll and carotenoids, respectively, in drought-treated only seedlings (DS) compared to the untreated ones.

Moreover, drought stress reduced the pigment contents more than in the seedlings inoculated with Ta only. Pigment contents in Ta + DS were found to be greater than in the droughtstressed only (DS) seedlings (Figure 4).

\section{Ta Inoculation Under Drought Reduces Membrane Damage and $\mathrm{H}_{2} \mathrm{O}_{2}$ Accumulation}

An increase in MDA content was observed following drought stress. MDA content increased significantly by $32 \%$ in drought only treated seedlings (DS) in comparison to untreated seedlings (C). However, Ta colonization mitigated the lipid peroxidation under stress. The percentage increase in MDA content under stress was recorded to be $15.4 \%$ in Ta-colonized 

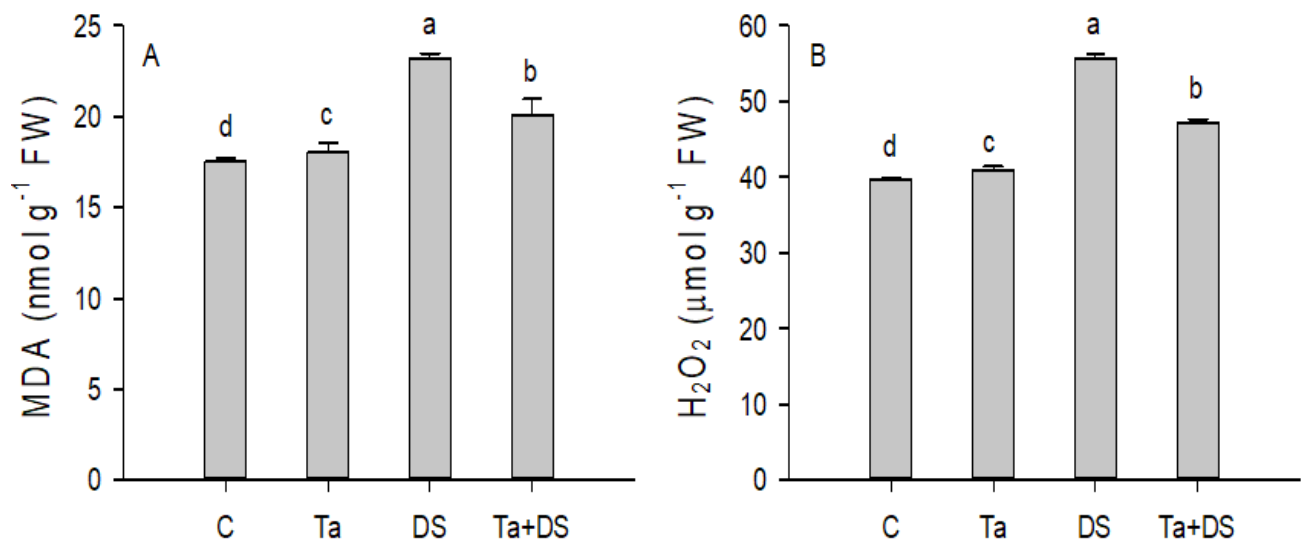

Figure 5. The potency of seed biopriming of T. atroviride strain ID20G on malondialdehyde (MDA) (A) and hydrogen peroxide $\left(\mathrm{H}_{2} \mathrm{O}_{2}\right)(B)$ contents of tomato plants under drought stress. The plants were subjected to four treatments: with distilled water (untreated control, C), with T. atroviride strain ID20G and not drought stressed (Ta), drought-stressed only (DS), and pre-treated with T. atroviride strain ID20G and drought stressed (Ta+DS). FW: Fresh weight. Vertical bars indicate standard deviation and different letters indicate significant difference $(P<0.05)$ among the treatments.

seedlings when compared to drought only treated seedlings (Figure 5A).

Drought also caused a severe $\mathrm{H}_{2} \mathrm{O}_{2}$ accumulation in the seedlings. The concentration of $\mathrm{H}_{2} \mathrm{O}_{2}$ increased significantly by $40.3 \%$ in drought only treated seedlings in comparison to the control. However, this change was less obvious in seedlings treated with Ta. Ta inoculation resulted in a substantial decline of endogenous $\mathrm{H}_{2} \mathrm{O}_{2}$ concentration under drought stress. The percentage increase in $\mathrm{H}_{2} \mathrm{O}_{2}$ concentration after Ta inoculation was recorded to $18 \%$ in comparison to drought only treated seedlings (Figure 5B).

\section{Ta Inoculation Under Drought Induces Antioxidant Eenzyme Activities}

Drought stress significantly induced and increased the antioxidant enzyme activities in tomato seedlings (Figure 6). The SOD, CAT, GPX, and APX activities increased to $40,78,118$, and $89 \%$ in drought stressed only seedlings compared to the untreated control group, respectively. It is obvious that the Ta inoculation alone (in the absence of drought stress) led to a significant increase in GPX and APX activities compared to the control (Figure 6C, D). However, no significant change in SOD and CAT activities between the control and Ta-inoculated seedlings was obtained (Figure $6 \mathrm{~A}, \mathrm{~B})$. In addition, the activities of antioxidant enzymes were significantly increased after root colonization with Ta under drought stress in comparison to drought only treated seedlings. The percentage increase recorded were $11 \%$, 19\%, 57\%, and $23 \%$ for SOD, CAT, GPX, and APX, respectively (Figure 6A, B, C, D).

\section{DISCUSSION}

Drought stress is one of the major stress factors in the environment that causes biochemical alterations in plants, including limiting plant growth and decreasing plant productivity. Plants develop different strategies to avoid drought stress. One of these strategies is the use of biocontrol agents such as Trichoderma due to its, effectiveness, and compatible nature with the ecology. Rhizosphere-competent fungus of the genus, Trichoderma plays an essential role in many metabolic processes of host plants tolerant to drought stress. This genus increases water holding capacity of plants, induces osmolyte synthesis to protect the plants from osmotic stress, helps in the uptake of crucial minerals, and enhances photosynthetic efficiency [20]. Although the abiotic stress tolerance-promoting capability of Trichoderma spp. in plants colonized with the fungi has been previously reported $[4,21]$ there is no information concerning drought tolerance responses in tomato induced by our local isolate, Ta. According to the best of our knowledge, the present study is the first one to discover the role of the local isolate, Ta candidate strain as a control agent in enhancing the tolerance of 

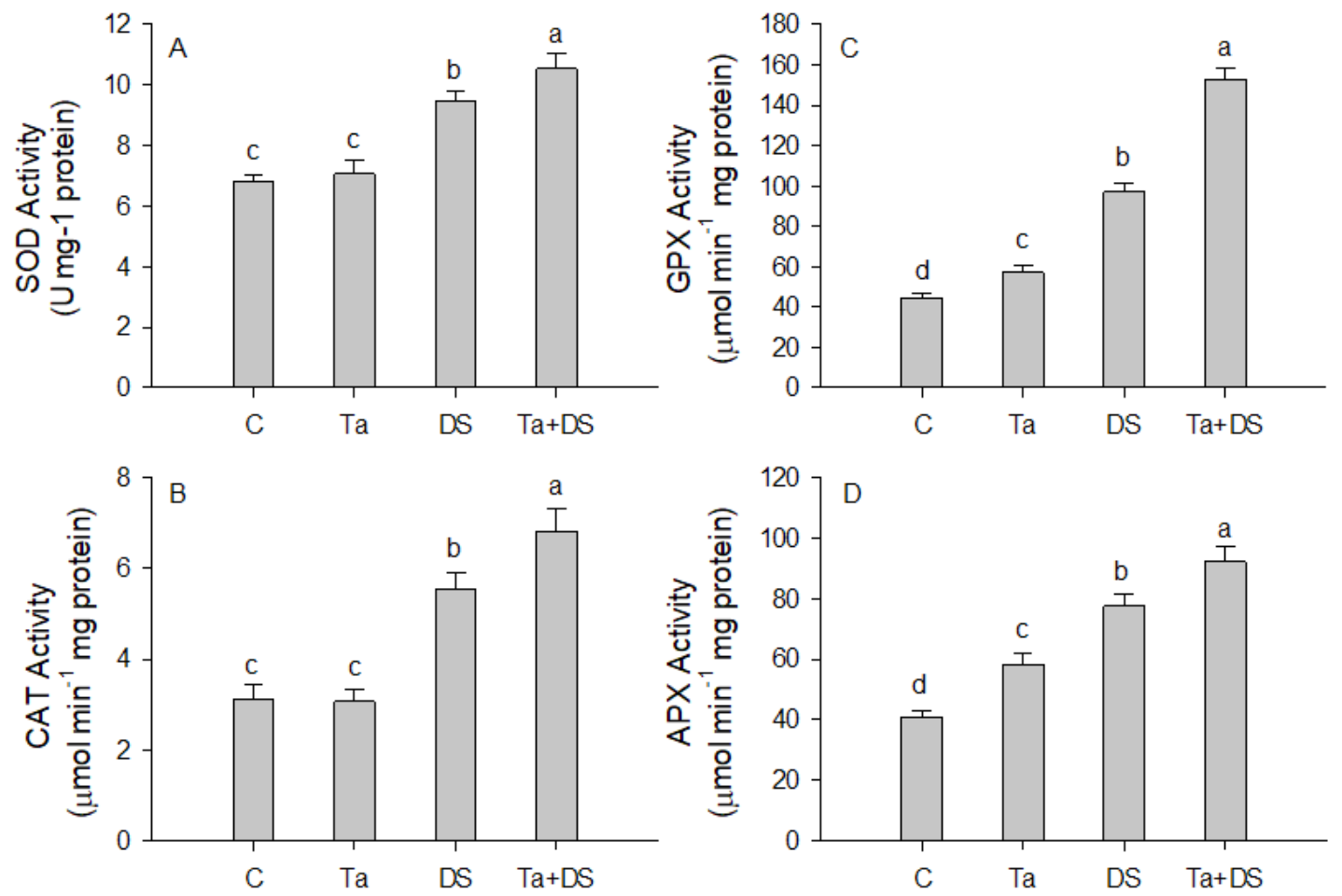

Figure 6. The potency of seed biopriming of $T$. atroviride strain ID20G on superoxide dismutase (SOD) (A), catalase (CAT) (B), guaiacol peroxidase (GPX) (C) and ascorbate peroxidase (APX) (D) enzyme activities of tomato plants under drought stress. The plants were subjected to four treatments: with distilled water (untreated control, C), with $T$. atroviride strain ID20G and not drought stressed (Ta), drought-stressed only (DS), and pre-treated with $T$. atroviride strain ID20G and drought stressed (Ta+DS). Vertical bars indicate standard deviation and different letters indicate significant difference $(P<0.05)$ among the treatments.

tomato seedlings to drought stress. Trichoderma genus can improve plant growth through various mechanisms, which include enhanced nutrient uptake and mineral solubilization, sequestration of inorganic nutrients, and promotion of root hair growth [6]. In this study, we checked the ability of our local isolate, ID2OG to enhance tomato growth. The root growth and leaf-root numbers were significantly higher in Ta-treated tomato seedlings as compared to the controls (Figure 3 ). The capability of Ta to produce phytohormones may serve as a fundamental factor in the elevation of components required for tomato growth. Better nutrient uptake by increasing the root number in seedlings treated with Ta enhances the physiological processes in tomato seedlings, thereby leading to good growth performance.

It is well illustrated that drought stress inhibits the photosynthetic pigments in plant species. A decrease in the chlorophyll concentration under drought stress has been considered to be one of the main symptoms of oxidative injury; it might be a result of photo-oxidation and degradation of the pigment. Similarly, the loss of chlorophylls under water stress is the primary cause of photosynthesis inactivation [7]. Carotenoids, on the other hand, exert an antioxidant capacity and provide photoprotection to chlorophylls with ROS scavenging potential [22]. Therefore, a reduction in carotenoid content following drought stress results in the ROS overproduction. Indeed, it is clear that total chlorophyll and carotenoid contents were negatively affected by drought stress in the present work. However, less reduction in pigment contents was found in Tacolonized tomato seedlings. This data is consistent with the experiments of [23] who demonstrated increased chlorophyll content in the drought tolerant, T. hamatum DIS 219b-colonized plants. Additionally, Harman et al. [24] proved that $T$. harzianum (T22) improved leaf greenness in 
maize, which in turn makes more energy and carbon source to available for plant growth. Similar to the report of Harman et al. [24], our data indicated that the local isolate, Ta may lead to improved nutrient bioavailability by increasing the capacity of solubilization and/or chelation of essential minerals. Thus, pigment synthesis might be enhanced in tomato seeds inoculated with Ta. On the other hand, it is considered that Trichoderma genus plays a key role in releasing some metabolites analogous to phytohormones that balance growth under drought stress [25]. Based on the above information, we may conclude that increased pigment content after Ta colonization of tomato seedlings might be due to the production of some hormone or hormone-like metabolites, such as cytokinine-like molecules, e.g., zeatin, and gibberellins-related compounds that contribute to the protection of chlorophyll degradation.

Our data demonstrated that the MDA content significantly increased in the drought-stressed tomato seedlings as compared to control. However, a decrease in MDA concentration was detected in Ta-treated tomato seedlings. Based on the presented results, we may conclude that Ta inoculation abrogated the effects of lipid peroxidation and protected the tomato seedlings from oxidative injury. Moreover, root colonization by Ta increased the antioxidant enzyme activities that mitigate the ROS attacks on membranes, thereby decreasing the rate of lipid oxidation. It has also been proved that Trichoderma upregulates the expression of stress-related proteins, such as glutathione S-transferase (GST), glutathione-dependent enzymes (formaldehyde dehydrogenases), which may lead to the decrements in the MDA content [20]. Our data are compatible with the data obtained from chickpea, exhibiting greater MDA concentration for noninoculated plants than Trichoderma-inoculated ones [26].

Drought stress triggers the generation of ROS such as hydrogen peroxide in the cells. In tomato seedlings, drought stress triggered the accumulation of $\mathrm{H}_{2} \mathrm{O}_{2}$. However, Ta-treated seedlings exhibited low levels of $\mathrm{H}_{2} \mathrm{O}_{2}$ in the present study, which might provide protection against $\mathrm{H}_{2} \mathrm{O}_{2}$ accumulation by increasing its scavenging or avoiding its production under drought stress. The decrease found in $\mathrm{H}_{2} \mathrm{O}_{2}$ levels following Ta colonization corroborates with the conclusion of Shukla et al. [21] in rice plants. Furthermore, when ROS is generated, detoxifying enzymes act as defense molecules and reverse the impact of oxidative damage with the help of Trichoderma [21]. Similarly, Hajiboland et al. [27] demonstrated that tomato seedlings with arbuscular mycorrhizal fungi (AMF) performed better in terms of $\mathrm{H}_{2} \mathrm{O}_{2}$ accumulation, and in turn, mitigated the oxidative damage as compared to non-mycorrhizal plants.

The avoidance of oxidative damage has been reported as one of the vital processes of stress tolerance, and this type of protection mechanism is attributed to an improved antioxidant capacity within the cell. The findings from the present study demonstrated that drought stress induced higher levels of SOD, GPX, CAT, and APX activities in tomato seedlings than in the controls. Furthermore, root colonization by Ta resulted in a higher increase in the antioxidant enzyme activities of tomato seedlings, which is in accordance with the data of Mastouri et al. [4] who demonstrated the role of T. harzianum T22 in tomato plants in mitigating water stress by an anti-oxidative defense system. The detoxification enzymes might be $\mathrm{H}_{2} \mathrm{O}_{2}$ scavengers, thereby preserve the membrane integrity [21]. Our results suggested that the coordination of CAT, GPX, and APX activities along with SOD activity played a central protective role in the $\mathrm{H}_{2} \mathrm{O}_{2}$ scavenging process in tomatoes treated with Ta. The higher antioxidant enzyme activities by Ta coincided with a decrease in the concentration of $\mathrm{H}_{2} \mathrm{O}_{2}$ suggesting that root colonization by Ta improved the potential capability of tomatoes to scavenge $\mathrm{H}_{2} \mathrm{O}_{2}$ via the upregulation of antioxidant enzymes under drought stress. However, the difference in the levels of antioxidant activity in colonized and uncolonized tomato seedlings explains the ability of colonized plants to maintain a redox potential higher than the unstressed seedlings [4].

\section{CONCLUSIONS}

Soil environment is really complex and the interaction between plant and beneficial organisms living in the soil is of great importance 
in adapting plants to adverse abiotic stress conditions. From our data, it is clear that drought stress has been found to induce deleterious effects on tomato seedlings. However, Ta, as a seed inoculant, was found to mitigate the hazardous effects of drought. Root colonization by Ta restored the pigment contents and decreased the level of both MDA and $\mathrm{H}_{2} \mathrm{O}_{2}$ accumulation. Antioxidant enzyme activity, including SOD, GPX, CAT, and APX, was triggered by drought stress, as expected. However, root colonization by Ta further enhanced the activities of these enzymes, thereby protecting the tomato seedlings from further damage. Within this context, the data presented here provides evidence that our local Trichoderma fungal strain ( $\mathrm{Ta}$ ) as an organicbased abiotic stress biocontrol agent may be effective against damages induced by drought stress in the cells.

\section{References}

1. H.D.V. Saba, M. Manisha, K.S. Prashant, H. Farham, A. Tauseff, Trichoderma a promising plant growth stimulator and biocontrol agent, Mycosphere, 3 (2012) 524-531.

2. M. Tucci, M. Ruocco, L.D. Masi, M.D. Palma, M. Lorito, The beneficial effect of Trichoderma spp. on tomato is modulated by the plant genotype, Mol. Plant Pathol. 12 (2011) 341-354.

3. M. Farooq, A. Wahid, N. Kobayashi, D. Fujita, S.M.A. Basra, Plant drought stress: effects, mechanisms and management, Agro. Sust. Dev., 29 (2009) 185-212.

4. F. Mastouri, T. Bjorkman, G.E. Harman, Trichoderma harzianum enhances antioxidant defense of tomato seedlings and resistance to water deficit, Mol. PlantMicrobe Interact. J., 25 (2012) 1264-1271.

5. N.S. Guler, N. Pehlivan, S.A. Karaoglu, S. Guzel, A. Bozdeveci, Trichoderma atroviride ID20G inoculation ameliorates drought stress-induced damages by improving antioxidant defence in maize seedlings, Acta Physiol. Plant., 38 (2016) 132.

6. G.E. Harman, Overview of mechanisms and uses of Trichoderma spp. Phytopathol., 96 (2006) 190-194.

7. N. Shukla, R.P. Awasthi, L. Rawat, Seed biopriming with drought tolerant isolates of Trichoderma harzianum promote growth and drought tolerance in Triticum aestivum, Annals Appl. Biol., 66 (2015) 171182.

8. F.A.O. (2015). http://www.fao.org/faostat/en/\#data/ QC/visualize. [accessed December 2015]

9. H.T. Aldrich, K. Salandanan, P. Kendall, M. Bunning, F. Stonaker, O. Kulen, C. Stushnoff,. Cultivar choice provides options for local production of organic and conventionally produced tomatoes with higher quality and antioxidant content, J. Sci. Food. Agric., 90 (2010) 2548-2555.
10. S.A. Karaoglu, S. Ulker, Isolation, identification and seasonal distribution of soilborne fungi in tea growing areas of Iyidere-Ikizdere vicinity (Rize-Turkey), J. Basic Microbiol., 46 (2006) 208-218.

11. D.I. Arnon, Copper Enzymes in Chloroplasts, Polyphenoloxidase in Beta vulgaris, Plant Physiol., 24 (1949) 1-15.

12. E.M.J. Jaspars, Pigmentation of tobacco crowngall tissues cultured in vitro in dependence of the composition of the medium, Physiol. Plant., 18 (1965) 933-940.

13. R.L. Heath, L. Packer, Photoperoxidation in isolated chloroplast, I. Kinetics and stochiometry of fatty acid peroxidation, Arc. Biochem Biophys., 125 (1968) 189198.

14. V. Velikova, I. Yordanov, A. Edreva, Oxidative stress and some antioxidant systems in acid rain-treated bean plants, protective role of exogenous polyamines, Plant Sci., 151 (2000) 59-66.

15. M.M. Bradford, A rapid and sensitive method for the quantitation of microgram quantities protein utilizing the principle of protein-dye binding, Anal. Biochem., 72 (1976) 248-254.

16. C. Beauchamp, I. Fridovich, Superoxide dismutase: improved assays and an assay applicable to acrylamide gels, Anal. Biochem., 44 (1971) 276-287.

17. H. Urbanek, E. Kuzniak-Gebarowska, K. Herka, Elicitation of defense responses in bean leaves by Botrytis cinerea polygalacturanase, Acta. Physiol. Plant., 13 (1991) 43-50.

18. H.E. Aebi, Catalase, (Ed: Bergmeyer HU), Methods of Enzymatic Analysis. 3rd edn. Verlag Chemie, Weinheim, Florida, (1983) 273-286.

19. Y. Nakano, K. Asada, Hydrogen peroxide is scavenged by ascorbate-specific peroxidase in spinach chloroplasts, Plant Cell Physiol., 22 (1981) 867-880.

20. A. Hashem, E.F. Abd Allah, A.A. Alqarawi, A. Asma, A.A. Al-Huqail, D. Egamberdieva, Alleviation of abiotic stress in Ochradenus baccatus (Del.) by Trichoderma hamatum (Bonord.) Bainier, J. Plant Interact., 9 (2014) 857-868.

21. N. Shukla, R.P. Awasthi, L. Rawat, J. Kumar,. Biochemical and physiological responses of rice (Oryza sativa L.) as influenced by Trichoderma harzianum under drought stress, Plant Physiol. Biochem., 54 (2012) 78-88.

22. R.K. Behera, PC. Mishra, N.K. Choudhary, High irradiance and water stress induced alterations in pigment composition and chloroplast activities of primary wheat leaves, J. Plant Physiol., 159 (2002) 967-973.

23. H. Bae, R.C. Sicher, M.S. Kim, S.H. Kim, M.D. Strem, RL. Melnick, BA. Bailey, The beneficial endophyte Trichoderma hamatum isolate DIS 219b promotes growth and delays the onset of the drought response in Theobroma cacao, J. Exp. Bot., 60 (2009) 3279-295.

24. G.E. Harman, C.R. Howell, A. Viterbo, I. Chet, Trichoderma spp.: opportunistic avirulent plant symbionts, Nature Rev., 2 (2004) 43-56.

25. A. Martı́nez-Medina, M.D.M. Alguacil, J.A. Pascual, 
S.C.M. van Wees, Phytohormone profiles induced by Trichoderma isolates correspond with their biocontrol and plant growth-promoting activity on melon plants, J. Chem. Ecol., 40 (2014) 804-815.

26. L. Rawat, Y. Singh, N. Shukla, J. Kumar, Salinity tolerant Trichoderma harzianum reinforces $\mathrm{NaCl}$ tolerance and reduces population dynamics of Fusarium oxysporum f.sp. ciceri in chickpea (Cicer arietinum L.) under salt stress conditions, Arch. Phytopath. and Plant Protect., 146 (2013) 1442-1467.

27. R. Hajiboland, N. Aliasgharzadeh, S.F. Laiegh, C. Poschenrieder, Colonization with arbuscular mycorrhizal fungi improves salinity tolerance of tomato (Solanum lycopersicon L.) plants, Plant Soil., 331 (2012) 313-327. 